NGTT Deel 54, Nommers 3 \& 4, September en Desember 2013

Mouton, Elna

Stellenbosch University

\title{
"What is a woman that You are mindful of her?" Aspects of irony and honour in Luke 7:36-50 ${ }^{1}$
}

\begin{abstract}
Unlike the other three gospel writers, Luke places the account of a woman anointing Jesus outside the passion narrative, in the context of Jesus' ministry in Galilee. The article explores rhetorical mechanisms through which the narrator of Luke 7:36-50 presents the story of Jesus' anointing by a woman publicly known as "a sinner", while eating with a Pharisee named Simon. The passage is firstly situated within the broad literary context of Luke's gospel. A brief analysis of the narrative focuses secondly on Jesus' identity and authority as "a friend of sinners". The essay finally investigates aspects of irony and honour in the passage, with particular reference to the reversal of roles-both of the Pharisee and the woman.
\end{abstract}

The task of hermeneutical appropriation requires an integrative act of imagination ... (W)henever we appeal to the authority of the New Testament, we are ... placing our community's life imaginatively within the world articulated by the texts.

(Hays 1990:45-46)

I was privileged to contribute to a previous collection of essays in honour of Dirk J. Smit and am grateful for the opportunity to follow it up here (cf. Mouton 2007a). The previous essay discussed aspects of Smit's contribution to an ethos of responsible (biblical) hermeneutics, and his appropriation of biblical perspectives in contemporary Christian ethos and ethics. The crucial starting point of such an ethos, I argued, is the gift of "seeing" differently, of discerning faithfully, of imagining God's radical presence in the world. It is in this sense, I believe, that the significance of Smit's work - especially from within the dynamic yet complex interface between the biblical sciences and systematic theology - has to be appreciated.

As a celebration of and a humble tribute to Smit's lifelong devotion to the interpretation of the Bible in numerous church and societal contexts; as a token of my respect for his personal ethos and wisdom, his academic excellence and integrity, his passion for righteousness and the dignity of creation, I offer him my ongoing journey with Luke's account of an unnamed woman anointing Jesus (Lk. 7:36-50). ${ }^{2}$ The art of "seeing" - of recognising, of being aware, of acting boldly - plays an important role in the text, and in my analysis throughout.

1 The main title is derived from Psalm 8:4 and Hebrews 2:6.

2 An earlier (shorter) version of this essay was published as part of a Society of Biblical Literature project on Character Ethics and the New Testament as The Reorienting Potential of Biblical Narrative for Christian Ethos, with Special Reference to Luke 7:36-50 - cf. Mouton 2007b. It is used here with the permission of the publisher. 
NGTT: Oopbron - http://ngtt.journals.ac.za

\section{JESUS' LIBERATING AND HEALING MINISTRY}

Luke - unlike the other gospel writers - places the account of a woman anointing Jesus outside the passion narrative, in the context of Jesus' ministry in Galilee (Lk. 4:14 - 9:50). ${ }^{3}$ The Lukan narrator reconfigures the story of Jesus in a socio-political context probably after the JewishRoman war of 6670 CE. Of all the Jewish religious groups, only the Pharisees seem to have been able to regroup after the destruction of the temple, evidently with greater emphasis on the observance of (their interpretation of) torah than before. By 85 CE the Pharisees had accepted a clause in which the Jesus followers were cursed and banned from their synagogues (Bosch 1993:210).

Against this background the question may be raised of how Luke's audience was supposed to (re)imagine God through Jesus' response to the unnamed woman in Luke 7. I start with a brief look at the immediate literary context within which the anointment story is situated. In the Lukan narrative, 7:36-50 occurs after Jesus' authority as a teacher and healer has been revealed - inter alia by his sermon on the plain (6:17-49), the healing of a centurion's servant (7:1-10) and the raising of a widow's son from Nain (7:11-17). The story unfolds according to the programme Jesus announced in Nazareth (Lk. 4:16-21), whereby his earthly ministry

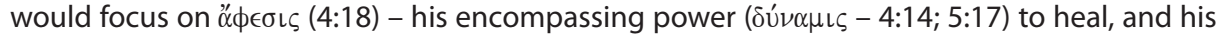
authority ( $\left.\xi^{\prime} \xi o v \sigma i \alpha-5: 24\right)$ to forgive sins and to free all kinds of captives (such as the poor and socially disowned, the sick and demonpossessed, strangers and outsiders). ${ }^{4}$

Beginning in 5:17, the narrator shows special interest in Jesus as proclaimer of the release from sins by artfully connecting a diverse group of stories related to this theme. As each new episode is sounded, the audience is able to recall and compare related episodes with enriching harmonies (Tannehill 1986:103-109). The story of the healing of the paralytic in Luke 5:17-26 is Jesus' first encounter with the scribes and Pharisees, and the beginning of a series of controversies with them (cf. 5:27-32; 7:18-50, et cetera). It is also the first reference in Luke to Jesus' forgiveness of sins, and is presented in such a way that the audience may know that Jesus' authority is epitomised by his divine power to release sinners $(5: 24)$.

Luke 7:36-50 is the final unit of the section 7:1-50, in which the relationship between the ministries of John the Baptist and Jesus has been the leitmotif. Luke 7:18-50 has a number of

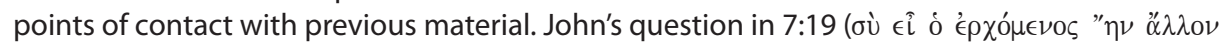

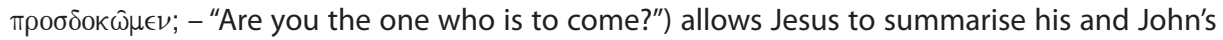
ministries in 7:22-28. ${ }^{5}$ In 7:29-30 the narrator remarks that all the people except the Pharisees

\footnotetext{
3 Scholars are puzzled as to how these accounts (Mk. 14:39; Mt. 26:6-13; Lk. 7:36-50; Jn. 12:18) are related. The resemblances and differences among them (and whether or not they refer to the same event or oral tradition) have been much debated. For discussions on these issues see Malone 2000:48-49; Pesonen 2000; Schaberg 1998:373-375; Bock 1994:689-693; Johnson 1991:128-129; York 1991:118-119.

4 All references to the Greek New Testament are from the UBS4/NA27 text. References to the English

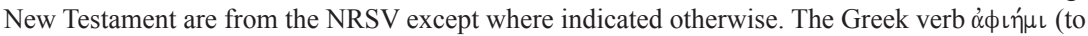
cancel a debt) often has a financial connotation (cf. Lk. 11:4; 16:5,7). The noun $\alpha$ $\phi \epsilon \sigma \iota \varsigma$ literally refers to the remittance of trespasses or the acquittal of a legally required sentence, without penalty or further obligation. This is the most common word group that Luke appropriates and reinterprets for the

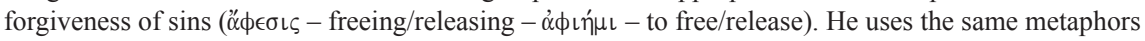
with regard to the uplifting or strengthening of the weak and the healing of illness. In all these instances uses of the profound image of acquittal of debt or release from prison (cf. Bosch 1993).

5 With reference to Jesus' response in 7:22-28, Sharon Ringe (2002:72-73) comments as follows: "If we look closely at the paraphrase of the Jubilee motifs from the texts of Isaiah found in the response to John
} 
NGTT Deel 54, Nommers $3 \& 4$, September en Desember 2013

and lawyers acknowledged God's purpose and were baptised by John (cf Mt. 21:31-32). ${ }^{6}$ In 7:31-35 Jesus responds to criticism of his association with tax collectors and sinners. This leads to the anointment story of 7:36-50, which illustrates the narrator's observation in 7:29-30 by way of an extreme example (cf. Corley 1993:122, 130-133). Jesus' response is concluded by

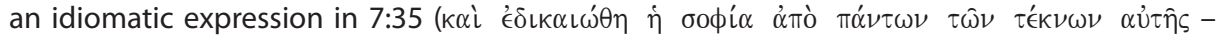
"Nevertheless, wisdom is vindicated by all her children"). It is probably a revised version of a saying from Q (cf. Mt. 11:19; Sirach 26:29), and suggests that Luke understands Jesus to say that "wisdom shows her true potential when a broad range of humanity is enclosed in her family" (Danker 1988:168) - including tax collectors, sinners and (other) outsiders. In the Lukan context divine wisdom is justified ("proven right" - NIV) over against/despite her children who have rejected her (Marshall 1978:303). It would also imply that wise people "prove their social abilities by the outcomes of their behaviour" (Malina and Rohrbaugh 2003:254-255). The narrative of 7:36-50 will exemplify this saying.

The anointment story of Luke 7:36-50 occurs directly before references to (other) women who served Jesus (8:1-3) and various parables that are all about listening, perceiving and understanding (cf. 8:4-21). This is followed by Jesus calming a storm, to which his disciples respond with fear and amazement, asking: "Who then is this, that he commands even the winds and the water, and they obey him?" (8:22-25). Further healings are reported (8:2656; 9:3743), Jesus sends out the twelve (9:19), feeds five thousand people (9:1017), and subsequently confronts his disciples with: "Who do you say that I am?" (9:18-21). Jesus announces his death for the first time (9:22-27), where after his identity is affirmed by a voice from the cloud ("This is my Son, my Chosen" - 9:28-36). He refers to his betrayal and death a second time, but the disciples (still) do not understand the meaning of his words (9:44-45). Jesus then uses a little child to explain what it means to be the greatest in God's kingdom (9:46-50), followed by the beginning of his journey to Jerusalem (9:51), where he will be executed by the religious leaders who "rejected God's purpose for themselves" (7:30).

Luke 7:36-50 thus occurs in a literary context of utterances on the radical nature of Jesus' divine power and authority (ultimately to forgive sins), God's alternative kingdom, prophetic wisdom, the Pharisees' (and the disciples') lack of understanding and the crowds' responses of amazement and awe.

With reference to the internal structure of 7:36-50, it may be helpful to analyse the story of the "woman in the city" in terms of three successive judgements about her (Cosgrove 2005:686):

an initial set of impressions prompted by the description of her in verses 37-38, Simon's interpretation of the woman's behaviour (v. 39), and Jesus' interpretation of both Simon's and the woman's behaviours (vv. 40-50).

... we are struck by something missing. There is no mention of 'release' or 'forgiveness'. Luke's story of the anointing of Jesus by the woman at the banquet in Simon's house (7:36-50) fills in that blank" (cf. n. 4 above).

6 Though Luke does not state it explicitly, the structuring of 7:18-50 suggests that the anointing woman's acquaintance with forgiveness (v. 47) may be an indication that she had been influenced by the ministry of John, and that her coming to Jesus is to express gratitude for the forgiveness proleptically bestowed on her by John (3:3; Corley 1993:125-127). 
The pericope's literary link to the previous passage is established at once by the introduction of the first (as yet unnamed) character, "one of the Pharisees" (7:36), and the fourfold repetition of "Pharisee" in 36-39. Jesus is invited by a Pharisee (later referred to as Simon) to have dinner at his house.7 Jesus "took his place at the table" (v. 36 - NRSV)/"reclined at the table" (NIV)/ ( $\kappa \alpha \tau \in \kappa i \dot{i} \theta \eta$ - aorist passive of $\kappa \alpha \tau \alpha \kappa \lambda i \nu \omega)$, which indicates that the Pharisee was hosting a significant meal, probably a luxury meal (Robbins 1996:90) - a formal banquet or Sabbath meal. "It was quite common to invite a visiting rabbi or teacher to the Sabbath meal after he had taught in the synagogue. If it was a banquet meal, Jesus may have been invited because of his reputation as a prophet" (Stein 1992:235-236; cf. Fitzmyer 1981:688). They were dining "in the Hellenistic manner which was to lounge on one's side, with the feet pointing away from the table" (Johnson 1991:127; cf. Malina and Rohrbaugh 2003:256; Taylor 2004:30-31, 42-45). The reclining posture (which the Jews had adopted for festive banquets) would have made Jesus' feet most accessible, and probably accounts for the coming attention to the feet. It may also be noted that in the ancient Near East the door of the dining room was left open so the uninvited could pass in and out during the festivities. They were allowed to take seats by the wall, listening to the conversation between the host and guests (Talbert 1984:86; cf. Cosgrove 2005:689 n. 49; Bock 1994:694).

In continuation of the theme of 7:34 (Jesus being called "a friend of sinners"), a second

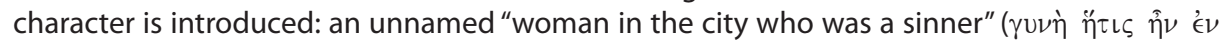
$\tau \hat{n}$ Tó $\lambda \in L \dot{\alpha} \mu \alpha \rho \tau \omega \lambda \lambda^{\prime} \varsigma$ - v. 37). By introducing the woman at the beginning of (what appears to be) the Pharisee's story, the narrator emphasises her role from the outset. Of particular

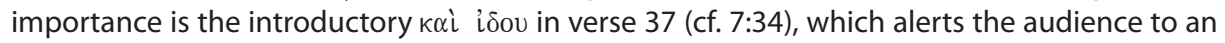
unusual development and important point to be made (Danker 1988:169), often associated with a prophetic utterance. According to Nolland (1989:353), it is best to connect 'e $v$ tn̂ $\pi{ }^{\prime} \lambda \in L$ $\omega \iota \tau \eta \dot{\alpha} \mu \alpha \rho \tau \omega \lambda$ ó $\varsigma$ and to give it a meaning like, according to Semitic idiom, "publicly known". He continues by saying that " $(t)$ he dramatic impact of the woman's actions appears most strikingly if 'sinner' is understood as a euphemism for 'prostitute' or 'courtesan'" (cf. Corley 1993:124-127, 24-79). ${ }^{8}$ As a member of the (silent) spectatoraudience, she takes initiative and boldly steps

7 This is the first of three such occasions where Jesus eats with a Pharisee, found only in Luke (cf. 11:3354; 14:1-24; Corley 1993:123). On each occasion Jesus' authority is put to the test, and he ends up at odds with his host. In fact, on each occasion Jesus' behaviour scandalises the host (cf. York 1991:122). These encounters emphasise the Pharisees' main shortcoming from Jesus' perspective, namely that their particular interpretation of Torah have resulted in a harsh view of, and a lack of compassion towards, socially disowned people (cf. references to seeing, watching, the eye in Luke 7:39, 44; 11:33-38). The fact that Jesus dines with Pharisees does not mean that they endorse what he has been doing, but rather gives an indication of his social standing as a wellknown teacher (Nolland 1989:360).

8 Luke introduces the woman as "a sinner" even though the context suggests that her sins were forgiven before she entered the Pharisee's house (note the repetition of the perfect passive $\alpha \phi \phi^{\prime} \omega \nu \tau \alpha \iota$ in vv. 47-48; cf Corley 1993:125). This seems strange, bearing in mind that Luke - more than the other Gospels generally focuses on marginalised groups while rendering women visible (cf. Dewey 1997). Is this a fair observation of her (historical) position at the time, or does it reflect the narrator's ironical way of drawing attention to her particular status in the presence of Pharisees? (cf. York 1991:122).

By identifying the woman as "a sinner" (cf. v. 39) Luke seems to emphasise her shameless status in the sociocultural context of his audience. (For a discussion on the probable audience of Lk. 14, cf. Van Staden 1991:199). Feminist critics such as Jane Schaberg and Mary Malone, assuming that the four Gospel accounts refer to the same event or tradition, point out that the Lukan interpretation of Mk. 14:39 changed the context and purpose of the woman's act remarkably. Schaberg (1998:375) argues that Luke 
NGTT Deel 54, Nommers 3 \& 4, September en Desember 2013

forward, bringing with her a precious alabaster jar of perfumed oil ( $\dot{\alpha} \lambda \dot{\alpha} \beta \alpha \sigma \tau \rho o \nu \mu u ́ \rho 0 u)$. The expensive soft alabaster was believed to help preserve ointments and perfumes (cf. Mk. 14:3).

The woman comes prepared in a way fit for anointing a king. Crossing her sociocultural boundaries (cf. Corley 1993:75-78), she steps into a public space where a ritually impure woman would not be expected to appear - least of all at a Pharisee's table! ${ }^{9}$ She stands behind Jesus at his feet, weeping, and begins to bathe his feet with her tears and to dry them with her hair. ${ }^{10}$ The story intensifies as the narrator reports: "Then she continued kissing his feet (katefi,lei - imperf.) and anointing them with the ointment" (v. 38). ${ }^{11}$

Jesus' passivity in the face of this behaviour is extremely eloquent (v. 39). That he allows the woman to act in this way evokes a negative response from his host. In a moral world where collective honour was a pivotal value, associating with, accepting the actions of or serving a shameless person would bring shame to oneself. In fact, to take a shameless person seriously and to show courtesy to her or him would make one a fool (Malina 1993:39, 45, 53-54; Malina and Rohrbaugh 2003:255; cf. York 1991:123 n. 4). When the Pharisee saw what the woman did,

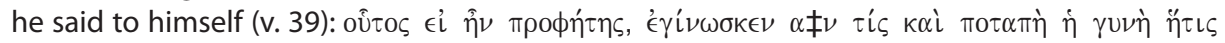

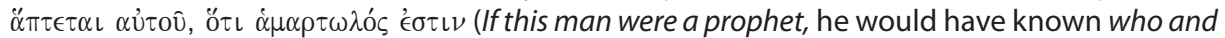
what kind of woman this is who is touching him - that she is a sinner). ${ }^{12}$

erased the female prophet by reducing the original story "to a display of unusual affection on the part of an intruding woman". Malone (2000:49) describes the Lukan version as "a remarkable gesture of sorrow by a repentant woman [that] has been beloved by countless numbers of artists in the Christian tradition. This is the conventional image of the woman, daughter of Eve, who knows her place because of her sinful nature." What most people remember about the anointing woman in Luke, they claim, is that she was a sinner (cf. Ringe 2002:73), presumably a prostitute (sometimes with reference to her unbound hair, even though unbound hair could also be associated with women prophesying - cf. 1 Cor. 11:56; Taylor 2004:3942; Cosgrove 2005:687691; n. 11 below). Schaberg (1998:375) then concludes: "Given the emphatic nature of Mark 14:9, Luke's editing displays real arrogance. Politically, prophetically, what she has done will not be told in memory of her." From the point of view of the narrative's probable redaction history, and history of interpretation, the point is valid. However, I shall deal with it as a distinct event in the Lukan literary context, presumably with a particular implied rhetorical purpose.

9 According to Malina $(1993: 39,51)$, an honourable person in the firstcentury Mediterranean world would be "one who knows how to and can maintain his or her social boundaries in the intersection of power, gender, and social respect, including God. The shameless person is one who does not observe social boundaries ... one outside the boundaries of acceptable moral life, hence a person who must be denied the normal social courtesies." Moreover, this woman's behaviour would probably not comply with ritual purity laws of (popular) Judaism at the time (cf. Neyrey 1991a:375382; Malina and Neyrey 1991:3438, 63; Sanders 1992:229230; Moxnes 1986:160161; n. 12 below).

10 For a discussion on the social symbolism of a woman's unbound hair in the ancient Mediterranean world, see Cosgrove 2005. With reference to Luke 7:3650, Cosgrove $(2005: 691$; cf. 687688) concludes "that the woman's gesture with her hair is not sexually provocative, indecent, or even a breach of etiquette". Since unbound hair on a weeping woman in the firstcentury Mediterranean world would naturally be associated with grief, supplication or gratitude, Luke's audience could have interpreted the woman's emotions along similar lines (cf. Cosgrove 2005:689; Corley 1993: 127-130).

11 Commenting on these actions, Nolland (1989:354355) remarks that "the accidental fall of tears on feet begins a chain reaction: with nothing at hand to remove the offending tears, the woman makes use of her letdown hair; the intimate proximity thereby created leads to a release of affectionate gratitude expressed in kissing the feet ... and the anointing perfume, no doubt intended for the head (since only this has a place in Jewish custom) but finding no ready access thereto, is spent upon that part of Jesus' body with which the woman has already made intimate contact."

12 As with table fellowship, the separation between the pure and impure had much to do with what or whom could be touched and what or whom not (Johnson 1991:127; Malina and Neyrey 1991:54-58; cf. 
NGTT: Oopbron - http://ngtt.journals.ac.za

Apparently it is not the intrusion of a woman per se that was such a shock and a scandal to Simon's Pharisaic sensibilities, but that it was this particular woman:

Yet worse ... was the failure of his guest, Jesus, to repulse her attentions ... Jesus accepts it all and Simon is confirmed in his scepticism about the popular view that Jesus might be a prophet (cf. 7:16; 9:19). Ironically, Jesus, aware both of the woman's condition and of Simon's state of mind, fulfils precisely Simon's conception of prophetic awareness (Nolland 1989:361) [emphasis mine]. ${ }^{13}$

\section{(Re)imagining God through Jesus' ReSPONSE}

The Pharisee's observation in verse 39 puts the central issue of the narrative, namely Jesus' authority and identity - and thus his honour - on the table (cf. v. 49).

By accepting the actions of a shameless person, Jesus was bringing shame to himself. He therefore could not possibly be God's prophet. However, the story makes clear that ... rather than losing his own honour, Jesus restores the honour of the woman (York 1991:123).

At the same time, two ironic references to seeing in verses 39 and $44-i \delta \omega \dot{\nu}$ and $\beta \lambda \epsilon ́ \pi \epsilon \iota \varsigma$ respectively - emphasise the Pharisee's inability to see, to observe, to perceive, to recognise, to be aware, to understand, to discern prophetically (by implication, like Jesus and like the woman; cf. Taylor 2004:72-76; Smit 2002; 2003; Mouton 2007a).

Jesus subsequently becomes the first character to speak in the story. Aware of the Pharisee's thinking, he takes initiative - addressing the Pharisee by his name ${ }^{14}$ - and tells him a brief story of a certain creditor who had two debtors. One owed 500 and the other 50 denarii (a denarius being around the usual day's wage for an agricultural labourer - Johnson 1991:127).

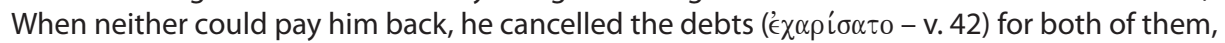
without any further obligation. The spare reporting of the parable may suggest that the focus

Lev 5:23; 6:18, 27; 7:20; 22:49). On touching an unclean woman, see Lev. 13; 15:19-32; Num. 12:10-15. "The host's identification as a Pharisee ... suggests that the purity of the table may have been a significant issue, especially if the woman was a Gentile" (Taylor 2004:35; cf. Sanders 1985:212-221; 1992:438-443; Elliott 1991).

For a second time the woman is referred to as "a sinner" (vv. 37, 39). According to Malina and Rohrbaugh (2003:251), making judgements about people was a common feature of the gossip network in honourshame societies. In such societies gossip functioned "as an informal means of social control. 'Judging' ... is largely a matter of stereotyping, usually entailing negative judgement or condemnation. Labels placed on people (sinner, tax collector, woman of the city, artisan's son) are shorthand honor designations that pigeonhole them and thereby both describe and determine honor status. They also provide others with a guide and control for social interaction." The main quality of such relationships is favouritism (cf. Mouton 2002:72 n. 21).

13 It is not clear from the context whether the idea that Jesus might be a prophet "was one to which Simon had himself been inclined, or whether he repeats popular sentiment (cf. 7:16; 9:19) only to criticize it. The latter is more likely ... Behind Simon's thought lies the unexpressed assumption that a prophet would maintain the same respectable distance as Simon himself would from a notorious sinner. The underlying scandal of Jesus' behavior is here once again that he is a friend to tax collectors and sinners (v. 34)"

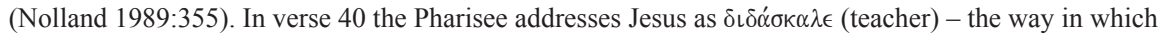
Jesus was usually addressed by non-disciples (cf. 8:49; 9:38).

14 This is unique to the passage - elsewhere in Luke, Pharisees are not introduced by name. For the relation between honour and naming in Mediterranean culture, cf. Malina and Neyrey 1991:32-34. 
NGTT Deel 54, Nommers 3 \& 4, September en Desember 2013

of interest is on what is to come in Jesus' followup question. Jesus interrogates Simon in the socalled Socratic style (Danker 1988:170-171; Talbert 1984:86) by asking: "Now which of them will love ('́) $\alpha \pi \eta \dot{\sigma} \sigma \iota)$ him more"; that is, would be more grateful? (Johnson 1991:127). The Pharisee responds rather half-heartedly by saying: "I suppose the one for whom he cancelled

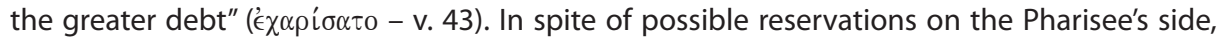
Jesus commends his answer. ${ }^{15}$

Turning towards the woman, Jesus then says to Simon: "Do you see this woman?" (B $\lambda \epsilon ́ \pi \epsilon\llcorner\varsigma$

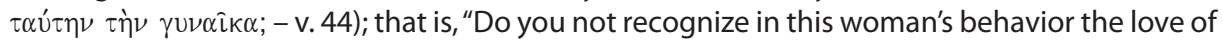
one who has been forgiven much?" (Nolland 1989:356, 361; cf. Pillay 2005:448-450). Jesus now interprets her courageous actions towards him by contrasting it to the Pharisee's omission of the appropriate hospitality rituals - water for cleansing his feet, a kiss of greeting and oil for anointing his head (vv. 44-46). ${ }^{16}$ Jesus uses the parable in vv. 41-42 ironically to show why she has performed such a special act of hospitality, thereby implicitly unmasking Simon's failure to accept God's forgiveness and love. ${ }^{17}$ Since Simon does not recognise the relationship between the woman's actions (37-38) and the parable, Jesus uses the latter artistically "to uncover the equivalence, by retelling vv. 37-38 in light of vv. 40-42" (Nolland 1989:357) [emphasis mine]. In the new version,

Jesus describes not only Simon, but also the woman, as performing the role of the host. As a host Simon has not been impolite or rude. Throughout, his behavior has been correct, but only correct. By contrast the woman has shown those marks of thoughtfulness and honor which would mark the hospitality of a host who owed a debt

15 See Malina 1996:143-175 on patronclient relationships as a probable analogy for the theologies of the Synoptic Gospels. As usually happens in the Gospel accounts, in this story too Jesus (and in the final instance God) ironically becomes the ultimate patron who shows compassion to socially disowned people. Such a shift would necessarily have generated social dynamite in Luke's day.

16 To provide water for guests to wash their feet after travel is well attested, but is not indicated in Jewish literature to be a normal provision for guests (Nolland 1989:357; cf. Marshall 1978:312). Likewise, in firstcentury Palestine, it was customary to anoint the head with oil at formal meals. As a sign of honour, a host would generally pour oil on the hair of wealthy guests as they arrived at the meal (Malina and Rohrbaugh 2003:255; Taylor 2004:45-50). However, it would not necessarily be expected of a host to extend this courtesy.

As with providing water and oil to guests, neither the kiss of greeting was mandatory as a mark of hospitality, even though it was an accepted form of greeting (cf. Lk. 22:48). The use of the verb katafi,le,w in this context "is the more intense form of the verb used to describe the kiss of the father at the return of the prodigal son (Luke 15:20) and the kiss of the elders upon Paul's farewell in Ephesus (Acts 20:37). The act of kissing and anointing the feet expresses deep reverence" (Bock 1994:697; cf. Malina and Neyrey 1991:55). Jesus hyperbolically allows the woman's kisses of greeting to be part of his welcome, thereby ascribing honour to her and casting her in the honorary role of hostess (cf. Cosgrove 2005:690-691; Malina and Neyrey 1991:47-49).

I have not found any evidence to suggest that different social codes applied to Sabbath meals than would be applicable to general firstcentury Jewish meals, except for considerable focus on the precise time for the Sabbath meal, i.e. when the Sabbath began (cf. Neyrey 1991a:367). Hence I assume that these general codes would also be customary at a Sabbath meal.

17 Whatever the significance of the anointment of Jesus' feet (cf. Jn. 12:3, versus the anointing of his head in Mk. 14:3; Mt. 26:67 - cf. Malina 1993:39-42; Taylor 2004:50-58), the point seems to be that her actions went beyond the normal courtesy of washing a guest's feet with water (cf. Fitzmyer 1981:691). In fact, olive oil would have been a cheap substance for anointing in comparison to perfume (Marshall 1978:312). The narrator powerfully expresses this dramatic contrast and irony through the rhetorical

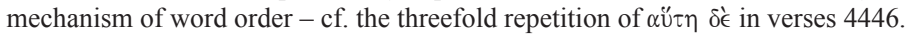


NGTT: Oopbron - http://ngtt.journals.ac.za

of affectionate gratitude to his (sic) guest. It is precisely in that which goes beyond the immediate polite demands of respectability that this woman's true attitude comes to expression (Nolland 1989:361).

Jesus then concludes their dialogue in an explicit way: "Therefore, I tell you, her sins, which were many, have been forgiven (' $\phi^{\prime} \in \hat{\epsilon} \omega \nu \tau \alpha \iota$ - perfect pass.); hence she has shown great love" (ö $\tau \iota$ $\left.\eta \gamma \alpha \dot{\pi} \eta \eta \in \mathcal{L} \pi \mathrm{r} \lambda u^{\prime}\right)$. The point seems to be clear: Because her many sins were forgiven, she honours Jesus lavishly in a moment of sacred affection and gratitude (cf. v. 42). She was prepared to welcome God's mighty intervention into her life - literally and ironically to host God's love and

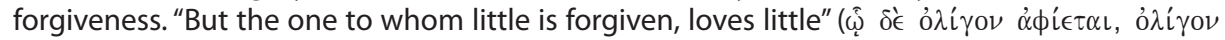
$\dot{\alpha} \gamma \alpha \pi \hat{\alpha}-$ v. 47).

At this significant moment in the narrative Jesus turns to the woman and says to her (v. 48):

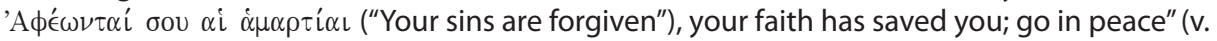
50). ${ }^{18}$ Up to this point it seems that Jesus has (quietly) allowed the woman's display of affection without directing his attention to her. However, by deliberately turning towards her, Jesus now draws together the threads from 37-39 and 40-43. As a result the other guests are amazed

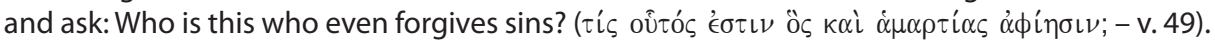
Could this amazement reflect their recognition of God's wisdom behind the actions of both Jesus and John - wisdom which here has found yet another of her children (v. 35)?

The unconventional story of Jesus' anointing by this woman in Simon's house conveys an ironical reversal of the roles of both characters initially presented in the story:

In the beginning the Pharisee is the host, the woman is a sinner. He is inside; she is outside. He has honor; she is shameless. As the story develops, she acts hospitably; he fails to show any special kindness towards Jesus. She understands him to be a prophet; he rejects Jesus' prophetic character. She is forgiven much and loves much; he is forgiven little and loves little ... She now has honor; Simon is shamed. The outsider has become an insider; Simon, the supposed insider, has become an outsider (York 1991:125-126; cf. Corley 1993:130).

As Jesus applauds the woman's actions, she becomes an exemplary figure. The suggestion that she (metaphorically) becomes Jesus' host, associates her with the women mentioned in the next narrative. They are his patrons, "providing for him out of their resources" (Lk. 8:23).

18 Whereas the connection between the woman's forgiveness and Jesus' authority has been implied throughout the pericope, it now becomes explicit by means of Jesus' authoritative word (in 5:20 for the first time, and here as confirmation of the restored relationship with God). Of significance is the recurrence of the two semantically related verbs cari,zomai (to forgive/release) and $\dot{\alpha} \phi\llcorner\eta$ « (to cancel a debt) in verses 42, 4749 (cf. Ringe 2002:73; n. 4 above). To send someone away with "go in peace" was a common farewell formula in Judaism (cf. Lk. 8:48). Here it takes on deeper significance in the coming of God's eschatological salvation. Jesus' pronouncement of peace to this woman (v. 50) is the pronouncement of God's encompassing righteousness and conciliation (wholeness, salvation, holiness, shalom) to her (cf. Bosch 1993:33).

Since the grammar does not make it clear, there is, however, a possible contradiction between the woman's receiving forgiveness from Jesus (v. 48) and Jesus' attesting to some other forgiveness she had already received (v. 47). This would influence the interpretation of her gesture - as either asking for forgive ness or expressing her gratitude and devotion for having received it before (cf. Cosgrove 2005:689-692). "Does forgiveness evoke love, or does love earn forgiveness? Which came first ...? With that debate, we, like the host in the story, miss the point, since really forgiveness and love are inseparable" (Ringe 2002:73). 
NGTT Deel 54, Nommers $3 \& 4$, September en Desember 2013

Both the sinful woman and these women take care of him (Cosgrove 2005:691; cf. Moxnes 1986:161163; Pillay 2005:447-448).

In the final analysis the narrative of Luke 7:36-50 portrays Jesus as the one who has compassion for sinners, who liberates and heals them, and who allows them to serve him, even lavishly. This is how the Christian communities towards the end of the first century CE remembered Jesus of Nazareth (cf. MoltmannWendel 1982; Neyrey 1991a:378-380; Dunn 2003:543-611).

Yet, what would be the implied rhetorical effect of the passage? What was it supposed to do to its audience? How were they supposed to (re)imagine God through Jesus' response to the woman and the Pharisee? It seems that Luke was creating a particular frame of reference, a moral horizon, glimpses of an alternative world (with its own distinctive atmosphere and language, images, values, dispositions, habits) that was meant to be inhabited by Jesus' followers (cf. Meeks 1986; Elliott 1991:104-105; Ringe 2002:78-79; Smit 1991:59, referring to Lindbeck). How was this supposed to happen?

The narrator uses the story of a most unlikely character from within that moral world as a parable, a metaphorical lens through which the radical nature of Jesus' identity and ministry can be recognised. Jesus' prophetic wisdom - his reversal of the expected order - challenges the usual assumptions about what would be regarded as 'honourable' in a fundamental way. Although the anointing woman is mute throughout the story (cf. Dewey 1996; 1997), she is "open to God's mercy" and reveals "a more basic orientation to God" than does the Pharisee (Fitzmyer 1981:687). Through her actions she acknowledges Jesus'liberating, healing authority. Her great love for and gratitude towards him allows her to act freely and creatively, to boldly risk and be vulnerable, to imagine new possibilities of serving God amid sterile sociocultural and religious conventions. ${ }^{19}$

The story, however, remains open-ended with respect to its outcome. Later audiences are to fill gaps such as where the woman would find a safe moral environment after Jesus sent her away in peace (7:50), and as to where the Pharisee would find an alternative, creative space to engage his position in light of his encounter with the "friend of sinners".

What seems to be clear is that Jesus ironically and prophetically subverted the socioreligious status quo of popular Judaism in his time by recasting both the woman and the Pharisee in the honorary role of hosting God's love and forgiveness. Through the imaginative lens of the Lukan narrator, followers of Jesus - then and now - are invited to do likewise.

On the occasion of Dirkie Smit's sixtieth birthday, I extend my profound gratitude and respect to him for the extent to which he has been seeing differently, and has been grappling imaginatively and intelligibly with the radical consequences of Jesus' encompassing ministry for church and society - over many years and through numerous presentations and writings, in various contexts and genres.

\section{BiBLIOGRAPHY}

Bosch, D. J. 1993. Good News for the Poor ... and the Rich. Pretoria: CB Powell Bible Centre (Unisa). Bock, D. L. 1994. Luke (Vol. 1: 1:19:50; Baker Exegetical Commentary on the New Testament). Grand

19 Passivity and unwillingness to risk would be typical characteristics of (positive) "female shame" in an honourshame society (Malina 1993:50-53; cf. Malina and Neyrey 1991:44-46). 
NGTT: Oopbron - http://ngtt.journals.ac.za

Rapids, MI: Baker.

Corley, K. E. 1993. Private Women, Public Meals: Social Conflict in the Synoptic Tradition. Peabody: Hendrickson.

Cosgrove, C. H. 2005. A Woman's Unbound Hair in the GrecoRoman World, with Special Reference to the Story of the "Sinful Woman" in Luke 7:3650. JBL 124/4, 675-692.

Danker, F. W. 1988. Jesus and the New Age: A Commentary on St. Luke's Gospel. Revised and expanded ed. Philadelphia, PA: Fortress.

Dewey, J. 1996. From Storytelling to Written Text: The Loss of Early Christian Women's Voices. Biblical Theological Bulletin 26/2, 71-78.

Dewey, J. 1997. Women in the Synoptic Gospels: Seen but not Heard? Biblical Theological Bulletin 27/2, 5360.

Dunn, J. D. G. 2003. Jesus Remembered (Christianity in the Making, Vol 1). Grand Rapids, MI: Eerdmans.

Elliot, J. 1991. Household Meals vs. Temple Purity Replication Patterns in LukeActs. Biblical Theology Bulletin 21/3, 102-108.

Fitzmyer, J. A. SJ 1981. The Gospel According to Luke (I-IX): Introduction, Translation, and Notes (Anchor Bible Series 28). New York, NY: Doubleday.

Hays, R. B. 1990. ScriptureShaped Community: The Problem of Method in New Testament Ethics. Interpretation XLIV/1, 42-55.

Johnson, L. T. 1991. The Gospel of Luke (Sacra Pagina 3). Collegeville, MN: The Liturgical.

Malina, B. J. 1993. The New Testament World: Insights from Cultural Anthropology. Louisville, KY: Westminster John Knox.

Malina, B. J. 1996. The Social World of Jesus and the Gospels. London: Routledge.

Malina, B. J. and Neyrey, J. H. 1991. Honor and Shame in LukeActs: Pivotal Values of the Mediterranean World. In Neyrey, J. H. (ed.), The Social World of Luke-Acts: Models for Interpretation. Peabody, MA: Hendrickson, 26-65.

Malina, B. J. and Rohrbaugh, R. L. 2003. Social-Science Commentary on the Gospels. 2nd edition. Minneapolis, MN: Fortress.

Malone, M. T. 2000. Women and Christianity (Vol 1: The First Thousand Years). Maryknoll, NY: Orbis.

Marshall, I. H. 1978. The Gospel of Luke: A Commentary on the Greek Text (The New International Greek Testament Commentary). Exeter: Paternoster.

Meeks, W. A. 1986. The Moral World of the First Christians. Philadelphia. PA: Westminster.

MoltmannWendel, E. 1982. The Women Around Jesus: Reflections on Authentic Personhood. London: SCM.

Mouton, E. 2002. Reading a New Testament Document Ethically. Atlanta, GA: SBL/Leiden: Brill.

Mouton, E. 2007a. "Seeing" with Reverence: Dirk Smit on the Ethos of Interpretation. NGTT 38 (1 \& 2), 383396.

Mouton, E. 2007b. The Reorienting Potential of Biblical Narrative for Christian Ethos, with Special Reference to Luke 7:3650. In Brawley, R. L. (ed.), Character Ethics and the New Testament. Moral Dimensions of Scripture. Louisville, KY/London: Westminster John Knox, 3555.

Moxnes, H. 1986. Meals and the New Community in Luke. Svensk exegetisk årsbok 51, 158167.

Neyrey, J. H. 1991a. Ceremonies in LukeActs: The Case of Meals and TableFellowship. In Neyrey, J. H. (ed.), The Social World of Luke-Acts: Models for Interpretation. Peabody, MA: Hendrickson, 361387.

Neyrey, J. H. (ed.). 1991b. The Social World of Luke-Acts: Models for Interpretation. Peabody, MA: Hendrickson.

Nolland, J. 1989. Luke 1-9:20 (Word Biblical Commentary 35A). Dallas, TX: Word.

Pesonen, A. 2000. The Weeping Sinner: A Short Story by Luke? Neotestamentica 34(1), 87-102.

Pillay, M. N. 2005. Luke 7:3650: See this Woman? Toward a Theology of Gender Equality in the Context of HIV and Aids. Scriptura (89), 441-455.

Ringe, S. H. 2002. Luke's Gospel: “Good News to the Poor" for the NonPoor. In HowardBrook, W. and Ringe,

S. H. (eds.), The New Testament - Introducing the Way of Discipleship. Maryknoll, NY: Orbis, 62-79.

Robbins, V. K. 1996. Exploring the Texture of Texts: A Guide to Socio-Rhetorical Interpretation. Valley Forge, PA:Trinity.

Sanders, E. P. 1985. Jesus and Judaism. London: SCM.

Sanders, E. P. 1992. Judaism: Practice and Belief 63 BCE - 66 CE. London: SCM / Philadelphia, PA: Trinity.

Schaberg, J. 1998. Luke. In Newsom, C. A. and Ringe, S. H. (eds.), Women's Bible Commentary. Expanded 
NGTT Deel 54, Nommers $3 \& 4$, September en Desember 2013

edition with Apocrypha. Louisville, KY: Westminster John Knox, 363-380.

Smit, D. J. 1991. The Bible and Ethos in a New South Africa. Scriptura (37), 5167. Smit, D. J. 2002. "Seeing Things Differently": On Prayer and Politics. In Holness, L. and Wüstenberg, R. K. (eds.), Theology in Dialogue. Grand Rapids, MI: Eerdmans, 271-284.

Smit, D. J. 2003. On Learning to See? A Reformed Perspective on the Church and the Poor. In Couture, P. and MillerMcLemore, B. J. (eds.), Suffering, Poverty, and HIV-AIDS: International Practical Theological Perspectives. Cardiff: Cardiff Academic, 55-70.

Stein, R. H. 1992. Luke (New American Commentary 24). Nashville, TN: Broadman. Talbert, C. H. 1984. Reading Luke: A Literary and Theological Commentary on the Third Gospel. New York, NY: Cross Roads.

Taylor, B. 2004. Outrageous Women: A comparison of Five Passages within the Canonical and Empty Tomb Narratives emphasizing the Role of Women. Unpublished MA dissertation, University of Cape Town.

Tannehill, R. C. 1986. The Narrative Unity of Luke-Acts: A Literary Interpretation (Vol 1: The Gospel according to Luke). Philadelphia, PA: Fortress.

Van Staden, P. J. 1991. Compassion - The Essence of Life: A SocialScientific Study of the Religious Symbolic Universe Reflected in the Ideology/Theology of Luke. Hervormde Teologiese Studies, Supplementum 4.

York, J. O. 1991. The Last shall be First: The Rhetoric of Reversal in Luke. Journal for the Study of the New Testament. Supplement Series 46. Sheffield: JSOT.

\section{KEY WORDS}

Forgiveness

Pharisee

Honour \& shame

(Im)purity

Irony

Art of "seeing"

\section{TREFWOORDE}

Vergifnis

Farisieër

Eer \& skande

(on)reinheid

Ironie

Kuns van "sien"

Prof. Elna Mouton

Faculty of Theology

Stellenbosch University

Private Bag X1

Matieland 7620

emouton@sun.ac.za 